\title{
THE EFFECTIVENESS OF A VIRTUAL FIELD TRIP (VFT) MODULE IN LEARNING BIOLOGY
}

\author{
Norbaizura HARIS \\ Faculty of Education \\ The National University of Malaysia \\ Bangi-MALAYSIA \\ Kamisah OSMAN \\ Faculty of Education \\ The National University of Malaysia \\ Bangi-MALAYSIA
}

\begin{abstract}
Virtual Field Trip is a computer aided module of science developed to study the Colonisation and Succession in Mangrove Swamps, as an alternative to the real field trip in Form for Biology. This study is to identify the effectiveness of the Virtual Field Trip (VFT) module towards the level of achievement in the formative test for this topic. This study was conducted to 60 students employing a quasi-experimental design involving a treatment group taught using the VFT module and a control group who were taught using conventional methods. Analysis into the effectiveness of the virtual module was done descriptively, followed by inferential analysis involving the two-way ANOVA. The results showed significant differences in the mean scores of pre and post achievement between students taught using VFT and students who were taught using conventional methods for objective, structure and essay type questions. The study concluded that teaching and learning by using the VFT module, integrated with ICT, has a positive impact on student achievement whencompared to conventional methods. This study focuses on the use of the VFT recognizing that teachers are often unable to conduct a real field trip on location.
\end{abstract}

Keywords: Virtual Field Trip (VFT), computer-aided learning (CAL), biology learning, mangrove swamps ecosystem (MSE.

\section{INTRODUCTION}

The role of information technology has become so important, especially in the field of education, as a basis for knowledge dissemination. From 'board and chalk' teachers now havein the classroom a wide range of sophisticated electronic equipment, which may include some, or all, of the following-computers,projectors, liquid crystal display screens (LCD), cameras, digital videos and smart boards. Schools, teachers and students should take advantage of the available technology to aid the process of teaching and learning, especially computers and the internet (Zainuddin\&MohdAzam, 2010). The integration of technology in education, introduced by the Ministry of Education through the Computers in Education programme, focuses on four main subjects -the Malay Language, English, Science and Mathematics. Due to this initiative subject teachers are now trained to use computers to aid teaching (Abdul Wahab et al., 2006); in the context of science teaching 
and learning, a variety of techniques and training stages are employed so that the experience, interests and ability of the student is taken into account so that the learning and teaching of science is an exciting, fun and challenging experience forall students (Law, 2009).

According to Muslim \&SitiJamaliah (2010) and Sumintono et al. (2012), one of the measures of interest in learning about this subject is through the use of information and communication technology; for example, the use of simulation to improve the level of understanding and imagination of students in both theory and abstract sciences concepts.

The employment of a wide variety of teaching methods and techniques is at the heart of the teaching and learning process, because without it the lessons may be dull and tedious for the students of the $\mathbf{2 1}^{\text {st }}$ century who are used to, and familiar with, many different forms of digital media. One method that is often overlooked by Biology teachers is to take students to explore the environment on location through field studies (Wong, 2002). The teachers, with time and economic limitations, may only be able to finish the course in a conventional manner, often without considering a creative way to enhance conceptual understanding and achievement of their students in Biology, and in so doing will fail to develop existing skills in their students. To provide the students with the necessary skills required in our present time is a challenge and as such Sawchuk (2009) suggested that schools implement and monitor teaching to create 21st century skills such as critical thinking, the ability to analyse effectively, good ITC skills, creativity, collaboration and communication. It has been proven by experts that students with these skills are in high demand by employers in the global work market and they also aid entrepreneurial initiative.

Biology, one of the branches of science education, is more meaningful if students are given the opportunity to interact withthe environment as a class (Wong, 2002). The integration of technology in the form of the Virtual Field Trip (VFT) module is one method that can bring students closer to nature. According to Wong (2002) this method can indirectly improve students' cognitive processes and thinking skills leading to a better understanding of concrete Biology concepts. The implementation of teaching learning using this method is also seen to be fundamental to the success of educational development goals. One of the objectives of the curriculum is to develop and enhance creative thinking skillsin the student which can only be achieved through creative teaching (MohamadMohsin\&Nasruddin, 2008). Modifications and improvements that need to be introduced do not diminish the need for traditional teaching methods that are tried and tested. An awareness of the eclectic possibilitities that new technologies provide to educators will enable teachers to meet the demand for new and innovative thinking skills which are required in modern day Malaysia and enable its students to acquire them so that the country is ableto face an increasingly challenging global environment.

This is consistent with the goals of a Biology curriculum designed to provide students with skills and knowledge in science and technology and to make them able to solve problems and make decisions in everyday life based on scientific attitudes and moral values (PusatPerkembanganKurikulum, 2006). Implementation of a non-interactive learning process in conventional teaching causes students to pay less attention to the teacher leading to a poor student understanding and motivation (Chuang \& Cheng, 2005). Consequently, to meet the targetsfor the expansion of good interactive learning, teaching media, or modules with the integration of ICT are needed in classrooms.

The lack of innovative teaching methods in the science classroom has contributed to the low numbers of students opting for the science stream when entering the upper level in high school. According to statistics published by the Ministry of Education from 1981 to 
2010, the participation of middle school students in science has not led to the required ratio of 60:40 in later high school studies. The factors identified affecting the quality of teaching science in the classroom include a lack of enjoyment of the subject and students perception is that science as an academic subject is dull and boring; abstract science conceptsare difficult and they may not pass with high marks (Syed Zin, 2003). Other factors include exam-oriented teaching (Lim, 2007) which focuses on passing examswithout practical experimentation and field studies. Moreover, less than effective teaching ofdifficult topics and abstract scientific concepts (Rojahan, 2004) is often disappointing to the student. Enquiry learning is essential to engage the student in scientific investigation and the lack of it affects the interest and the abilitiy of students to actively engage in the sciences at high school level (Khalidah, 2002).

MohdAzhar and Osman (2004) also concluded from the findings of many scholars outside the country that teachers ignore the variety of teaching approaches which enable the student to absorb the creative literacy existing in the wider community. Frequently teachers do not utilize the wide variety of teaching methods readily available, such as storytelling, role- playing, mind maps, tours and inquiry. In the context of the Biology lesson, teachers do not always integrate the use of the natural world through field studies, experiments, demonstration and the use of information and communication technology (Hamsiah, 2004).

Hamsiah points out that the teacher should be able to accept students' ideas, thus encouraging them to ask questions, leading to positive student enquiry andan understanding of the composition and diversity of ideas, talent and behaviour necessary to develop higher order thinking skills in students. Moreover, according to Rinkevich (2011), teachers who are not creative in their teaching methods can reduce the intrinsic motivation of students in their classroom. Therefore, the use of VFT modules can provide opportunities for students to be autonomous in their work outside the classroom while intrinsic motivation will be enhanced, reducing student stress; this crucial combination of positive factors allowsconceptual learning in Biology to be more effective.

Nafishah (2007)in her study found that the main problem for teachers is the additional work of planning a field trip and preparing the necessary work papers, planning and execution of the domestic arrangements (hotels or camping, food etc) as well as the extra administration involved in obtaining permission from the education department and liaising with parents andpreparing before travelling to the actual location where the field is to be carried out.

According to her, the safety of students on field trips must be considered and that this may be a significant factor discouraging Biology teachers from taking their students on field trips. In addition, the cost and logistical problems must be considered, including the limited number of students who will attend (not all pupils in the class will be given permission by their parents) a field trip outside the classroom, posing yet another difficult problem for the teacher (Nafishah, 2007).

Therefore, the integration of technology, through a VFT enables all students to explore the places virtually, without the need to consider the issues of cost and other logistical aspects that a real field trip poses.

\section{VIRTUAL FIELD TRIP (VFT)}

The field study is a crucial part of science learning in which students will be exposed to the real world so that they can find, evaluate and appreciate what they have learned in a real context (Cram, 2004 and Foley, 2003). Teaching outside the classroom plays an 
important role in enhancing the understanding and higher order thinking skills of students in subjects highly relevant to living things and the environment (Bitgood, 1991 and Cram, 2004). This method is well suited to one approach of teaching Biology through inquiry findings. It emphasizes learning through experience and in which students find information, ask questions leading to an investigation of phenomena that occurin real life, providing the student with the opportunity to try to understand the concepts and principles being studied. Teachers will then guide students to understand the concept through inquiry results which are found by the studentsthemselves (Nafishah, 2007 and Bitgood, 1991).

The VFTs that have been widely used in schools in New Zealand through the website LEARNZ provide opportunities for students to find and collect information actively under the guidance of teachers with access to the internet (Nafishah, 2007). VFT application can provide insights into a real situation and encourage students to think actively toform and build their own knowledge.

Bitner (1999) concluded that the use of a VFT provides project-based learning where students are given a problem which they must try to solve through observation. A VFT, integrated with ICT, is able to develop higher order thinking skills in students through interactive media elements. The teacher's role is very important as facilitators so that learning objectives can be achieved. Learning activities using the VFT are well suited to promote naturalist multiple intelligence.

This intelligence has to do with nurturing information related to the natural environment, so crucial in today's world. As such, the student may develop a love for the natural environment, providing crucial motivation,enabling the student to correlate the life of flora and fauna studied in Biology (Bitner, 1999).

In this study the VFT is an interactive softwareprogramme, designed by the researcher, to cover the topic on Colonization and Succession in Mangrove Swamps, Biology Form Four. Three learning objectives were selected from the Biology syllabus: (i) describe the process of colonization and succession in mangrove swamp;(ii) distinguish between pioneer and successor species in mangrove swamp,and (iii) identify the adaptation of mangrove plants that survive in an extreme environment. Three objectives were chosen because field study methods are the suggested activities described in Biology Form Four Curriculum Specifications.

According to Cram (2004), this topic is suiTable: for learning in the virtual environment through the use of video, as the situation in a mangrove swamp is constantly changing at high tide and low tide. Thus, a VFT equipped with a photo gallery and video along with a clear explanation gives students the opportunity to explore and achieve the desired objectives.

The concepts of learning using a VFT include the theories of constructivism, information processing and cognition of multimedia learning. In the process of active learning students are defined as active individuals in constructing knowledge; constructivist elements are created using the VFT. Some of these elements include building communication columns in which students are able to contact the teachers as well asproviing the relevant links for students to explore topics in greater depth. This module also encourages a good response from students through reactive elements such as video to generate thought, build curiosity and enable deeper exploration.

The second theory implemented in this module is that of information processing, where students receive a stimulus or receive information from the environment through the 
senses that are transformed into neural information, which, in turn, enters the sensory register for a very short time. After the registrar sensory, information goes to the process of selective perception. According to Gagne (1985), the perception will produce new forms of input that will be sent to the short-term memory. Transforming information into short-term memory is by limited and to extend the period, Gagne (1985) recommends the process of repetition. Thus, this module can be accessed by students repeatedly until students reach the desired objectives. Information in short-term memory will enter longterm memory through the encoding process. Here, the information in the form of the initial perception and short-term memory may be transformed into meaningful information effectively and in a variety of forms.

The third learning theory used to design this software is theCognitive Theory of Multimedia Learning. This theory was put forward by Mayer, based on some previous theories. Mayer (2002), defines cognitive theory as three assumptions based on theories of how people learn from words and pictures; these are Dual Channel Assumptions, Limited Capacity Assumption and Active Processing Assumption. In the cognitive processes of word processing, the student, or learner, will pay attention to some of the words that produce some construction of sound in working memory. In the process of the cognitive selection of images, students pay attention to several aspects of the construction of some of the pictures producing images in working memory. Verbal reasoning involves the process of selecting words and phrasesand integrating these into the knowledge base. The cognitive theory of multimedia learning states that meaningful learning occurs when students engage in verbal reasoning and visual space processing. Thus, this module implements several multimedia elements as text, graphics, video and audio in delivering complex and abstract concepts more easily.

Based on the above, this study developed a VFT module that integrates the use of ICT for students to understand the topic of Colonization and Succession in Mangrove Ecosystems. Topics are selected based on the proposed learning activities and teaching of the Biology Syllabus Form Four, through field studies in order to achieve the learning objectives. This initiative is in line with the findings of Yustina (2010) and Attwood et al. (2005) which states that the ICT module provides learning opportunities that are both interactive and effective in improving a variety of skills and achievement in students.

This module is a medium of teaching and learning in a multimedia form which helps the students to understand and master the concepts and other aspects or components of learning, with greater clarity and depth eliminating the need for an actual field study of a mangrove swamp. Specifically, this study aims to examine the effectiveness of a VFT module in Biology for the topic of Colonization and Succession in Mangrove Ecosystems.

\section{OBJECTIVES}

Based on the problem statement that is presented, the study aims to:

$>$ Identify whether there is significant difference in the mean scores of overall achievement of students taught using the VFT compared with students taught using conventional methods for the topic of Colonization and Succession in Mangrove Ecosystems.

$>$ Identify whether there is a significant difference in the mean scores of achievement for the item's objectives, structure and essays of students who were taught using the VFT compared with students taught using conventional methods for the topic of Colonization and Succession in Mangrove Ecosystems. 


\section{RESEARCH QUESTIONS}

Based on the research objectives, the research questions are:

$>$ Is there a significant difference in the mean scores of overall achievement of students taught using the VFT when compared with students taught using conventional methods for the topic of Colonization and Succession in Mangrove Ecosystems?

$>$ Is there a significant difference in the mean scores of achievement for the item's objectives, structure and essays of students who were taught using the VFT with students taught using conventional methods for the topic of Colonization and Succession in Mangrove Ecosystems?

\section{RESEARCH HYPOTHESIS}

$>\mathrm{Ho}_{1} \quad$ No significant differences in the mean scores of overall achievement of students taught using the VFT when compared with students taught using conventional methods for the topic of Colonization and Succession in Mangrove Ecosystems.

$>\mathrm{Ho}_{2}$ No significant differences in the mean scores of achievement for the item's objectives, structure and essays of students who were taught using the VFT when compared with students taught using conventional methods for the topic of Colonization and Succession in Mangrove Ecosystems.

\section{METHODOLOGY}

\section{Research Design}

Referring to Campbell and Stanley (1963), this study uses quasi-experimental methods. Table: 1 summarizes the design of the study conducted.

Table: 1

Research Design

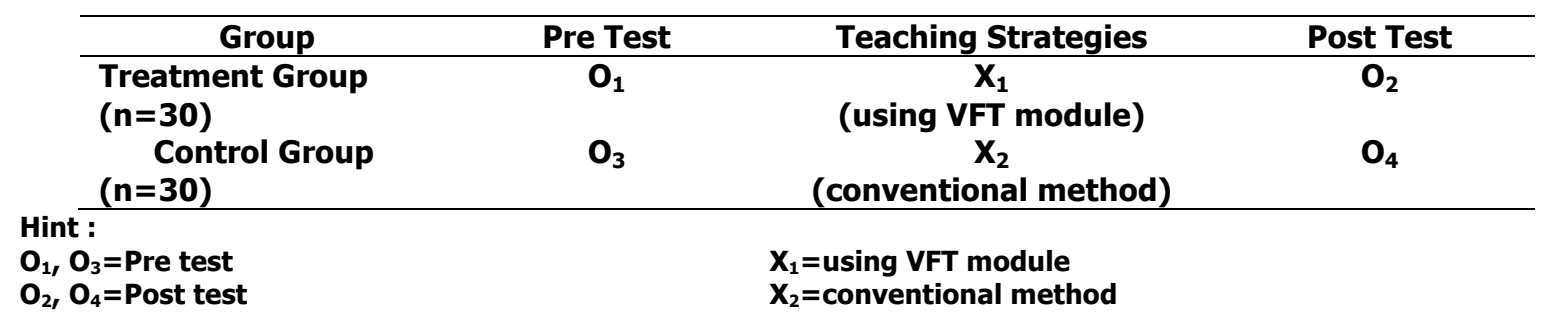

\section{Research Sample}

The sample consisted of $\mathbf{6 0}$ students from one of the schools in the stae of Selangor, Malaysia. Two groups of students were selected for the treatment group taught using the VFT module and the control group taught using conventional methods. Both groups of respondents were not obtained through a random selection procedure. Pairs of respondents have characteristics very similar to the treatment group and a control group without the use of random allocation procedure.

\section{Research Instrument}

The instrument used in this study is the formative test to measure student achievement in the topic of Colonization and Succession in Mangrove Ecosystems designed by the researcher and based on the format of SijilPelajaran Malaysia (SPM), which consists of both objective and subjective (structured and essays)questions. The objective part 
consists of fifteen questions that measure the constructs of knowledge and understanding (low level). The three subjective questions (structured) cover the constructs of knowledge, comprehension, application and analysis that are categorized as medium and high level questions. The construct evaluation emphasized in one essay question which is the high level questions.

Instrument Validity and Reliability

Validity and reliability of the VFT module are carried out to to get feedback from an expert teacher for the multimedia software built. The pilot study was conducted for the assessment of ICT covers the main menu display design, content material, graphics, animation and design operations. In all, the modules have high usability and effectiveness after some improvements as proposed.

The validity of achievement tests are based on the assessment of three Master Teachers of Biology. Schedule item specifications built on low-level, medium and high in 3:2:1 ratio was assessed by specialist teachers. Reliability achievement tests were obtained from a pilot study conducted on 30 students who have characteristics identical to actual samples.

The data is calculated using the Kuder Richardson $\mathbf{2 0}$ for the multiple choice, structure and essay questions. In this study, the Kuder Richardson 20 for objective part are 0.74, for structure is 0.73 and 0.68 for essay part. According to Nitko (2004) the reliability values above $0.7 \mathrm{can}$ be accepted and used in research. For subjective and essay items, the values of $\mathbf{0 . 6 5}$ and above are sufficient for research purposes.

\section{Research Procedure}

Before the test, the teacher will teach students to use VFT module in a computer lab where all students have the opportunity to explore their own topics studied: Colonization and Succession in Mangrove Ecosystems. For the experimental group, lesson started with a set of induction of a situation that needs to be completed by the student at the end of learning. Then, students will explore the VFT module supplied to seek answers to questions tested. Teachers act as facilitators to monitor the students and are willing to answer the questions posed. Upon completion of exploration through VFT modules, discussions will be conducted in order to make sure learning objectives are achieved. Then, students will answer questions to test the topics learned. For the control group, the same topics are taught using conventional methods.

\section{FINDINGS}

Differences Mean Scores of Overall Achievement of Students Taught

Using VFT with Students Taught Using Conventional Methods

for Topic of Colonization and Succession in Mangrove Ecosystems

Two-way ANOVA analysis is carried out to identify differences in mean total scores for students who were taught using the VFT with pupils conventional methods. Before the two-way ANOVA analysis conducted, Levene's test was conducted to determine similarity variables were compared. Levene's test results showed no significant variance-covarian among the dependent variables for all levels of the independent variable with the $F=\mathbf{2 6 6 8}$ and $s i g=0.051$ ( $p>0.05)$. This means that the variance-covarian dependent variable is homogeneous across the independent variables. Thus, the ANOVA test can conducted to examine differences in total mean scores for students who were taught using the VFT with students taught using conventional methods (Pallant, 2007). Two-way ANOVA analysis results shown in Table: 2 and Table: 3 below. 
Table: 2

Mean and standard deviation of difference mean scores for overall achievement of students taught using VFT and students taught using conventional methods

\begin{tabular}{clllc}
\hline Group & Time & N & Mean & Standard Deviation \\
& & & & \\
\hline Traetment & Pre & 30 & 26.73 & 16.438 \\
& Post & 30 & 66.80 & 11.248 \\
\multirow{4}{*}{ Control } & Total & 60 & 46.77 & 24.559 \\
& Pre & 30 & 20.60 & 12.574 \\
& Post & 30 & 29.00 & 16.871 \\
& Total & 60 & 24.80 & 15.348 \\
\hline
\end{tabular}

Table: 2 shows the group of students who were taught using the VFT shows the overall results of post-test (mean $=66.80$ and $S D=11248$ ) higher than the pre-test (mean=26.73 and $S D=16438$ ). Based on the conventional method of the students who showed posttest (mean=29.00 and $16871 \mathrm{sp}$ ) higher than pre-test scores (mean 20.60 and SD=12 574). To see the difference is statistically significant for both the teaching methods used then Two Way Anova test run. Two-way ANOVA test results as shown in Table: 3 below.

Table: 3

Two-way ANOVA difference between pre and post scores of the overall achievement of students taught using VFT with students taught using conventional methods

\begin{tabular}{lccccc}
\hline Independent Variable & $\begin{array}{c}\text { Type IIISum } \\
\text { of Squares }\end{array}$ & Df & Min Squared & F & Sig. \\
\hline Group & 14476.033 & 1 & 14476.033 & 68.979 & 0.000 \\
Time & 17617.633 & 1 & 17617.633 & 83.949 & 0.000 \\
Group * Time & 7520.833 & 1 & 7520.833 & 35.837 & 0.000 \\
\hline
\end{tabular}

Table: 3 shows significant differences in overall achievement scores of students taught using the VFT with students taught using conventional methods for the topic of Colonization and Succession in Mangrove Ecosystems with the $F=68979$ and sig=0.000 $(p<0.05)$. This shows that the null hypothesis (Ho1) is rejected. The findings also show that there is a significant interaction between group and time of the overall achievement. Because there are significant interactions then the form of increased for pre- and posttest scores is described as shown in Figure 1 below. 


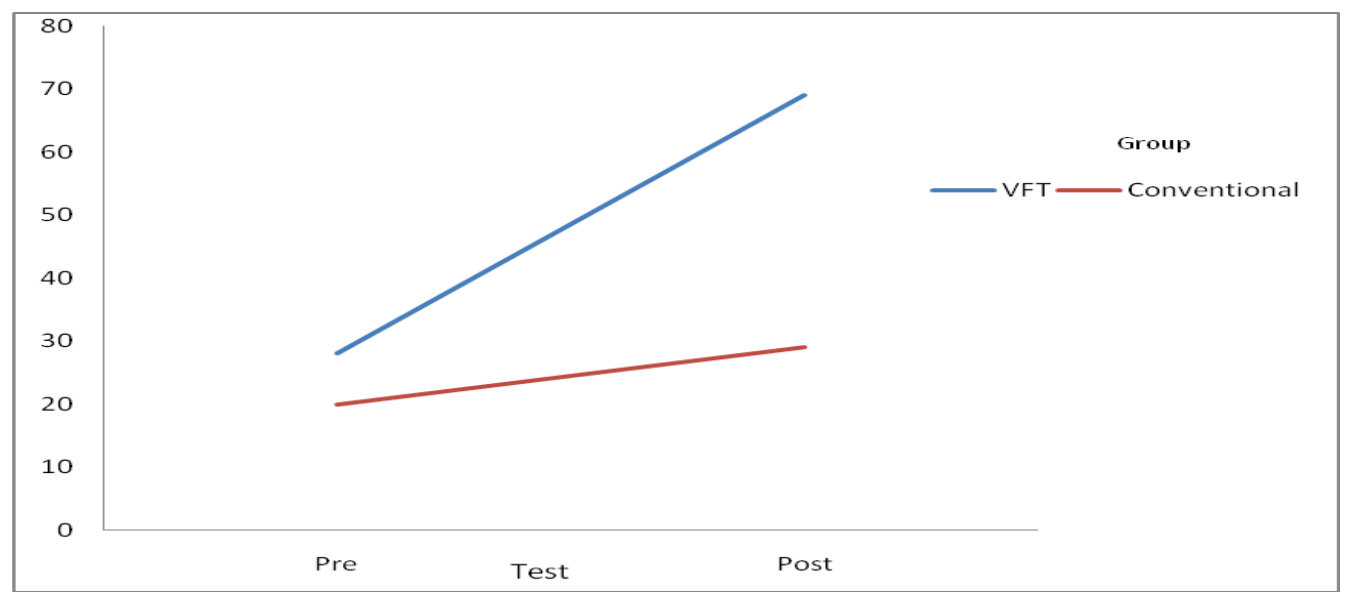

Figure: 1

Mean Difference Scores Pre- and Post- for Overall Achievement for Students Taught Using VFT with Students Taught Using Conventional Methods

Figure: 1 shows that students taught using VFT showed a higher improvement in overall achievement than the students taught using conventional methods.

Difference mean scores of Objectives Item for Students Taught

Using VFT with Students Taught Using Conventional Methods

for Topic of Colonization and Succession in Mangrove Ecosystems

Two-way ANOVA analysis carried out to identify the differences in mean scores of achievement for objective items students using VFT with students taught using conventional methods. Before the two-way ANOVA analysis conducted, Levene's test was conducted to determine similarity of variables that were compared. Levene's test results showed no significant variance-covarian among the dependent variables for all levels of the independent variable with the $F=18752$ and $s i g=0.000(p<0.05)$. This means that the variance of the dependent variable-covarian is not homogenous across the independent variables. Two-way ANOVA can be conducted to compare the mean scores of achievement for objective items for students taught using VFT with students taught using conventional methods because the number of samples for each group is 30 (Pallant, 2007).

Table: 4

Mean and standard deviation of the difference mean scores of objective items for students taught using VFT with students taught using conventional methods

\begin{tabular}{clccc}
\hline Group & Time & N & Mean & $\begin{array}{c}\text { Standard } \\
\text { Deviation }\end{array}$ \\
\hline Treatment & Pre & 30 & 42.22 & 20.367 \\
& Post & 30 & $\mathbf{8 9 . 3 3}$ & 7.345 \\
& Total & 60 & 65.78 & 28.190 \\
Control & Pre & 30 & 39.56 & 18.769 \\
& Post & 30 & 57.78 & 26.686 \\
& Total & 60 & 48.67 & 24.650 \\
\hline
\end{tabular}

Table: 4 shows a group of students who were taught using VFT shows post test achievement for the objective items (mean=89.33 and SD=7.345) higher than the pre test (mean=42.22 and SD=20 367). Based on the conventional method of the students who showed post test (mean $=57.78$ and $S D=26686$ ) higher than pre test scores (mean 
39.56 and SD=18 769). To see the difference is significant for both method,then Two Way Anova test run.

Two-way ANOVA test results as shown in Table: 5 below.

Table: 5

Two-way ANOVA results for the difference in mean scores of objective items for students taught using VFT with students taught using conventional methods

\begin{tabular}{lcccccc}
\hline Independent Variable & $\begin{array}{c}\text { Type IIISum } \\
\text { of Squares }\end{array}$ & Df & $\begin{array}{c}\text { Mean } \\
\text { Squared }\end{array}$ & F & Sig. \\
\hline Group & $\mathbf{8 7 8 3 . 7 0 4}$ & $\mathbf{1}$ & $\mathbf{8 7 8 3 . 7 0 4}$ & $\mathbf{2 2 . 9 1 6}$ & $\mathbf{0 . 0 0 0}$ \\
Time & $\mathbf{3 2 0 1 3 . 3 3 3}$ & $\mathbf{1}$ & $\mathbf{3 2 0 1 3 . 3 3 3}$ & $\mathbf{8 3 . 5 2 1}$ & $\mathbf{0 . 0 0 0}$ \\
Group * Time & 6259.259 & $\mathbf{1}$ & $\mathbf{6 2 5 9 . 2 5 9}$ & $\mathbf{1 6 . 3 3 0}$ & $\mathbf{0 . 0 0 0}$ \\
\hline
\end{tabular}

Table: 5 shows that there is significant difference in the achievement of the objective itemsfor students taught using VFT with students taught using conventional methods for the topicof Colonization and Succession in Mangrove Ecosystems with the value of $F=22$ 916 and sig=0.000 ( $p<0.05)$.

This shows that the null hypothesis (Ho2) is rejected. The findings also show that there is a significant difference between groups and time in the test results for the objective items.

Differences mean scores of Structured Items for Students Taught

Using VFT with Students Taught Using Conventional Methods

for Topic of Colonization and Succession in Mangrove Ecosystems

Two-way ANOVA analysis carried out to identify differences in mean scores for the structureditems for students taught using VFT with students taught using conventional methods. Before the two-way ANOVA analysis conducted, Levene's test was conducted to determine similarity of variables that were compared.

Levene's test results showed no significant variance-covarian among the dependent variables for all levels of the independent variable with the value of $F=1.453$ and sig=0231 $(p>0.05)$.

This means that the variance-covarian dependent variable is homogeneous across the independent variables.

Two-way ANOVA can be conducted to compare the mean scores of achievement for the structure items using VFT with students taught using conventional methods (Pallant, 2007).

Two-way ANOVA analysis results shown in Table: 6 and Table: 7 below. 
Table: 6

Mean and standard deviation of the mean difference scores for the structured items for students taught using VFT with students taught using conventional methods

\begin{tabular}{cllll}
\hline Group & Time & N & Mean & Standard Deviation \\
& & & & \\
\hline Treatment & Pre & 30 & 23.67 & 19.931 \\
& Post & 30 & 60.47 & 17.449 \\
& Total & 60 & 42.07 & 26.253 \\
Control & Pre & 30 & 15.73 & 13.243 \\
& Post & 30 & 18.87 & 16.389 \\
& Total & 60 & 17.30 & 14.857 \\
\hline
\end{tabular}

Table: 6 shows a group of students who were taught using the VFT shows the post test results for the structured items (mean $=60.47$ and $S D=17449$ ) higher than the pre test (mean=23.67 and SD=19 931). Based on the conventional method of the students who showed post test (mean=18.87 and $S D=16$ 389) higher than pre-test scores (mean=15.73 and SD=13 243). To see the difference is significant for both statistical methodology that was used then Two Way Anova test was run.

Two-way ANOVA test results isas shown in Table: 7 below.

Table: 7

Two-way ANOVA results for the difference in mean scores of structured items for students taught using VFT with students taught using conventional methods

\begin{tabular}{lcccccc}
\hline Independent Variable & Type IIISum of Squares & Df & Mean Squared & F & Sig. \\
& & & & & \\
\hline Group & 18401.633 & 1 & 18401.633 & 64.246 & 0.000 \\
Time & 11960.033 & 1 & 11960.033 & 41.756 & 0.000 \\
Group * Time & 8500.833 & 1 & 8500.833 & 29.679 & 0.000 \\
\hline
\end{tabular}

Table: 7 shows significant differences in the mean scores of achievement for the structured itemsfor students taught using VFT with students taught using conventional methods for the topicof Colonization and Succession in Mangrove Ecosystems with the value of $F=64.246$ and $s i g=0.000$ ( $p<0.05$ ). This shows that the null hypothesis (Ho3) is rejected. The findings also show that there is a significant difference between groups and time in the structured item of the test results.

\section{Difference mean scores of Essay Item for Students Taught \\ Using VFT with Students Taught Using Conventional \\ Methods for Topic of Colonization and Succession in Mangrove Ecosystems}

Two-way ANOVA analysis carried out to identify the differences in mean scores of achievement for students taught using VFT with students taught using conventional method in essay item. Before the two-way ANOVA analysis conducted, Levene's test was conducted to determine similarity of variables that were compared. Levene's test results showed no significant variance-covarian among the dependent variables for all levels of the independent variable with the value of $F=2409$ and $s i g=0.071(p>0.05)$. This means that the variance-covarian dependent variable is homogeneous across the independent variables. 
Table: 8

Mean and standard deviation of the mean difference scores

for the essay for students taught using VFT

with students taught using conventional methods

\begin{tabular}{llccc}
\hline Group & Time & N & Mean & Standard Deviation \\
\hline Treatment & Pre & 30 & 11.17 & 12.295 \\
& Post & 30 & 47.50 & 14.548 \\
& Total & 60 & 29.33 & 22.671 \\
Control & Pre & 30 & 5.00 & 8.610 \\
& Post & 30 & 9.17 & 11.453 \\
& Total & 60 & 7.08 & 10.263 \\
\hline
\end{tabular}

Two-way ANOVA can be conducted to compare the mean scores of achievement for students taught using VFT with students taught using conventional methods (Pallant, 2007) for essay item. Two-way ANOVA analysis results areas shown in Table: 8 and Table: 9.

Table: 8 shows a group of students who were taught using the VFT shows the post-test results for the essay items (mean=47.50 and $S D=14$ 548) higher than the pre-test (mean=11:17 and SD=12.295). Based on the conventional method of the students who showed post-test (mean $=9: 17$ and $s p=11453$ ) higher than pre-test scores (mean=5.00 and $S D=8610$ ). To see the difference is significant for both statistical methodology that was used then Two Way Anova test run. Two-way ANOVA test results as shown in Table: 9 below.

Table: 9

ANOVA bilateral differences in mean scores for the essay item pupils using pupils VFT with conventional methods

\begin{tabular}{lcccccc}
\hline & Type IIISum of Squares & Df & Mean Squared & F & Sig. \\
Independent Variable & & & & & \\
\hline Group & 14851.875 & 1 & 14851.875 & 104.566 & 0.000 \\
Time & 12301.875 & 1 & 12301.875 & 86.613 & 0.000 \\
Group * Time & 7760.208 & 1 & 7760.208 & 54.637 & 0.000 \\
\hline
\end{tabular}

Table: 9 shows that there is significant difference in achievement scores for essay items for students taught using VFT and students taught using conventional methods for the topic of Colonization and Succession in Mangrove Ecosystems with the value of $F=104.566$ and $s i g=0.000$ ( $p<0.05)$. This shows that the null hypothesis (Ho4) is rejected. The findings also show that there is a significant difference between groups and time in the test results for the essay items.

\section{DISCUSSION}

Based on the findings, it was found that the achievement of students taught using the VFT is higher than students taught using conventional methods. This is due to the usability and effectiveness of the VFT module developed by the researcher. This study was supported by the findings of Yustina (2010) and Attwood et al. (2005) which states that the ICT module provides learning opportunities that is interactive, effective and can improve a variety of skills and achievement among students. Presentation of concepts in the topics using graphic and video elements adds interest and excitement for students, and this helps them to focus on teaching. Lowe (2001) says that screening of animation 
and video can explain the situation that changes all the time so that it could help explain the procedure or order of occurrence. Learning that facilitates students to think systematically and corresponds to the learning objectives to be achieved.

Students who use VFT have a higher achievement in all three types of items which are the objectives, structured and essay than students taught using conventional methods which only showed improvement in objective items.

This proves that the use of VFT can encourage higher order thinking skills of students compared to conventional methods. This is because the questions posed in the objectives part are low level questions and stuctured and essay items iare high level questions that require students to think in order to answer the questions.

This finding coincides with the opinion of Bitner (1999) that the application of VFT can provide insight into real life situations and encourage students to think actively in the forming of knowledge.

Teaching and learning with encouraging environment in VFT allow students to participate in the entire learning process. This means that students are actively involved in the lesson so that they receive meaningful experiences that encourage them to think and find answers in learning (Rajendran, 2001 and Jackson, 2008).

The opportunitiesfor improvement derived from the teaching and learning methods used. So, using the appropriate materials allows for increased performance in general or specifically.

These findings were consistent with the findings of Rinkevich (2011) that the use of various teaching methods can provide an opportunity for students to enhance intrinsic motivation and conceptual learning will be more effective in biological subjects.

Hamsiah study (2004) also agrees that teachers who often use a variety of approaches such as the use of ICT can improve student achievement because of a clearer statement and interesting delivery of concept.

In addition, the use of VFT could provide an opportunity for students to explore the mangrove ecosystem not in their area. Students can see a graphical display and video clearly which help to improve their achievement in the topic of Colonization and Succession in Mangrove Ecosystems.

This is in accordance with the opinion of Bitner (1999) that the multimedia elements available in VFT provide exposure to the students so that they can find, evaluate and appreciate what they have learned in a real context.

The learning activities in VFT are matched to promote multiple intelligences nature naturalist. This intelligence has to do with nurturing the natural environment-related information, for students to reach a deeper understanding.

\section{CONCLUSION}

The results show that teaching and learning strategies using VFT have a positive impact on students' achievement in all forms of questions which are objective questions (lower level), structured and essays questions (high level) compared to the conventional method which only showed a good performance in objective items. 
Consequently, educators need to plan their Biology lesson by finding another teaching alternative if they cannot take students into the real field trip. The findings of this study can improve the quality of education through innovative teaching using VFT. If the lesson is well planned, achievement and students' thinking skills can be increased to a higher level. The parties responsible will have to formulate an appropriate mechanism to raise the level of preparedness of teachers and students to use the teaching and learning approach that integrates the use of ICT which has been proven very effective through this study.

\section{BIODATA and CONTACT ADDRESSES of theAUTHORS}

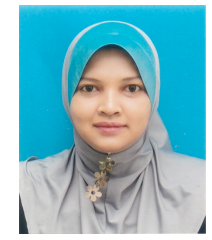

Norbaizura HARIS is currently pursuing her master's study in Science Education at the Faculty of Education, the National University of Malaysia.

Norbaizura HARIS

Faculty of Education

The National University of Malaysia

Bangi-MALAYSIA

Email: zuraharis@yahoo.com

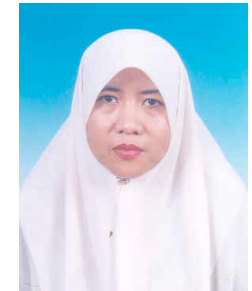

Kamisah OSMAN is currently the Deputy Director, Centre of Quality Assurance, the National University of Malaysia. She obtained her Masters in Science Education from the Centre for Science and Technology Education, The University of Manchester, UK in 1996 and continued her doctoral study soon after that at the same university. In 1999, she successfully completed her Phd in Science Education and then joined the National University of Malaysia as a Science Education Lecturer in 2000. Her research interest includes science education, thinking skills as well as curriculum innovation. Besides, she is also immersing herself in maintaining the Quality Assurance and Programme Accreditation processes, not only at the university level, but also national and international levels.

Kamisah OSMAN

The National University of Malaysia

Bangi-MALAYSIA

Tel: $\quad+60389214899$ (Office):

+60192884814 (HP)

Email: kamisah@ukm.edu.my

\section{REFERENCES}

Abdul, W. I. G., Kamaliah, S. \& Hasrina M. (2006). Penggunaan Komputerdalam Pengajaran-Pembelajarandalam Kalangan Guru Sekolah Menengah: SatuKajian Kes di Pulau Pinang. Jurnal Kajian Malaysia, 24(1\&2), 203-225.

Attwood, T. K., Selimas. L, Buls, R., Herzog, R., Ladent, V., Ghita, V., Fernandes, F., Marques, I. \& Brugman, M. (2005). Report on the Ember Project-a European Multimedia Bioinformatics Educational Resource. Journal BEE-j. Retrieved on February 25, 2013 from http://www.bioscience.heacademy.ac.uk/journal/vol6/beej-6-4.pdf.html 
Bitgood, S. (1991). What Do We Know About School Field Trips? Social Education, 62(1), 35-40.

Bitner, N. (1999). The Virtual Trip.Learning and Leading with Technology,26(6), 6-9.

Chuang, L. Y. \& Cheng, H. Y. (2005).The Development of Multimedia Courseware for Biotechnology.International Journal of the Computer, the Internet and Management, 13(3), 35-44.

Cram, W. J. (2004). Seeing Mangrove Swamps from a Distance : Development of a Virtual Field Trip. CAL-laborate: United Kingdom.

Foley, K. (2003). The Big Pocket Guide to Using \& Creating Virtual Field Trips (3rd ed.). Tramline.

Gagne, R. M. (1985). The Conditions of Learning and Theory of Instruction. Holt, Rinehart and Winston.

Hamsiah, S. (2004). TahapKreativiti Guru Sains Dan Amalannya Dalam Pengajaran. Retrieved on February 25, 2013 from http://www.ipbl.edu.my/BM/penyelidikan/jurnalpapers/Jurnal2004/ham2004.pdf

Jackson, R. (2008). Students can Learn on Their Own.

Retrieved on February 25, 2013 from http://teacherneedhelp.com/students

Khalidah, A. (2002). Faktor-faktor yang Mempengaruhi Keberkesanan Penerapan Proses Sains: Amalan di Kalangan Guru-guru Sains di Daerah Pontian. Master Dissertation, UTM.

Law, N. (2009). Mathematics and Science Teachers' Pedagogical Orientations and Their Use of ICT in Teaching. Education and Information Technologies, 14(4), 309-323.

Lim, T. C. (2007). Hubungan Antara Pendekatan Pengajaran Guru dengan Pendekatan Pembelajaran Pelajar Mata Pelajaran Kimia Tingkatan Empat. Master Dissertation, UTM.

Lowe, R. K. (2001). Beyond 'Eye-Candy': Improving Learning with Animations. Retrieved on February 25, 2013 from http://auc.Uow.edu.au/conf01/pdf

Mayer, R. E. (2002). Aids to Computer Based Multimedia Learning. Learning and Instruction, 12, 125-139

Mohd, A. A. H., \& Othman A. Kassim.(2004). Pemurnian KreativitiDalam PendidikanPrasekolah Sebagai Asas Pembinaan Bangsa Malaysia yang Kreatif: Suatu Kupasan Awal. JurnalKemanusiaan, 27-47.

Mohamad, M. M. S., \& Nasruddin, Y. (2008). Peranan Guru dalam Memupuk Kreativiti Pelajar.Jurnal Pengajian Umum, 9, 57-71.

Muslim, J. \& Siti J. Mat Junos @ Yunus.(2010). Pembangunan Perisian Alat Bantu Mengajar (ABM) Berasaskan Komputer Bertajuk Cell Division: Meiosis dalam Matapelajaran Biologi KBSM TingkatanEmpat. Retrieved on June 4, 2013 from http://eprints.utm.my/11164/1/Pembangunan_Perisian_Alat_Bantu_Mengajar.pdf 
Nafishah, H. (2007). Keberkesanan Kajian Pembelajaran Berbantu Komputer (Penggunaan Internet-Virtual Field Trips) Terhadap Penguasaan Konsep Sains. Retrieved on February 25, 2013 from http://eprints.oum.edu.my/176/1/Penggunaan_internet.pdf

Pallant, J. (2007). SPSS Survival. A Step-by-Step Guide to Data Analysis using SPSS for Window (version 10). New South Wales, Australia. Allen \&Unwin.

Pusat, P. K. (2006). Huraian Sukatan Pelajaran Biologi Tingkatan Empat. Selangor: Kementerian Pelajaran Malaysia.

Rajendran, N. S. (2001). Pengajaran Kemahiran BerfikirAras Tinggi: Kesediaan Guru Mengendalikan Proses Pengajaran Pembelajaran. Retrieved on June 4, 2013 from http://nsrajendran.tripod.com/Papers/PPK12001A.pdf

Rinkevich, J. L. (2011). Creative Teaching: Why it Matters and Where to Begin. Clearing House, 84(5), 219-223.

Rojahan, A. (2004). Pencapaiandan Kesalahan Konsepdalam Kerja, Tenagadan Kuasa di Kalangan Pelajar Tingkatan Lima AliranTeknikal. MA thesis, UM.

Sawchuk, S. (2009). Backers of $21^{\text {st }}$ Century Skills' Take Flak.Education Week, 28(23), 1-2.

Sumintono, B., Wibowo, S. A., Mislan, N., \&Tiawa, D. (2012). Penggunaan Teknologi Informasidan Komunikasidalam Pengajaran: Surveipada Guru-guru Sains SMP di Indonesia. JurnalPengajaran MIPA, 17(1), 122-131.

Syed Zin, S. M, (2002). Education in Malaysia.Retrieved on August 17, 2013 from http://www.ibe.unesco.org/curriculum/China/Pdf/IIMalaysia.pdf

Wong, M. N. (2002). A Comparative Study on The Effectiveness of Virtual Field Trip and Real Field Trip Concerning Biology Teaching in Secondary School. Retrieved on June 4, 2013 from http://hub.hku.hk/bitstream/10722/36520/1/FullText.pdf?accept=1

Yustina. S. (2010). Pembinaandan Keberkesanan ModulPembelajaran Alam Sekitar.Unpublished Phd Thesis.Universiti Kebangsaan Malaysia.

Zainudin, H. \& Muhammad, A. J.(2010). Penggunaan Komputerdan Internet dalam Pengajaran dan Pembelajaran di Kalangan Guru Sekolah Menengah di Daerah Pasir Mas, Kelantan. Retrieved on August 17, 2013 from http://eprints.utm.my/11440/1/Penggunaan_Komputer_Dan_Internet_Dalam_Pengajaran_Dan_P embelajaran_Di_Kalangan_Guru_Sekolah_Menengah_Di_Daerah_Pasir_Mas.pdf 